\title{
E-learning Barriers in the United Arab Emirates: Preliminary Results from an Empirical Investigation
}

\author{
Lejla Vrazalic ${ }^{1}$, Robert MacGregor ${ }^{2}$, Donna Behl ${ }^{3}$ and Jean Fitzgerald ${ }^{4}$ \\ ${ }^{1}$ Middlesex University Dubai, Dubai \\ 2 University of Wollongong, Wollongong, Australia \\ ${ }^{3}$ HCT Dubai Women's College, Dubai, UAE \\ ${ }^{4}$ Abu Dhabi, UAE
}

\begin{abstract}
E-learning is relatively new to the United Arab Emirates. Most tertiary institutions have allocated ICT resources to provide alternatives to the previously used teacher-centred "chalk and talk" approach to learning and teaching. However we have not yet developed a comprehensive understanding of the application of e-learning methods and resources in the tertiary education sector in the UAE. This paper describes a collaborative research project which empirically investigated the perceived barriers to elearning for students studying at tertiary institutions in the UAE using an online questionnaire. The paper analyses the associations between e-learning barriers and students' age and gender. The ease of use, usefulness and satisfaction with e-learning are also examined in relation to e-learning barriers. The preliminary research findings presented here will inform faculty who are integrating technology in their teaching and the tertiary institutions encouraging the use of e-learning as an integral part of the learning environment.
\end{abstract}

Keywords: e-learning, barriers, UAE

\section{Introduction}

Tertiary education institutions in the UAE are preparing students for a rapidly changing information and technology driven world. The UAE needs graduates who are ready for the workplace and who have a high level of knowledge and confidence in the use of technology to help them in their lifelong learning. The UAE is a small country of approximately 4 million inhabitants, situated at the toe of the Arabian Peninsula and is bounded by the Kingdom of Saudi Arabia and the Sultanate of Oman. Driven by oil discoveries, the UAE's vibrant economy has experienced unprecedented economic growth in the last 10 years. Described as one of the most-wired countries on earth [1] the UAE has been brought into the globalized world over the last 30 years since being an impoverished region of small desert principalities to becoming a modern independent country.
Universities and Higher Colleges of Technology in the UAE are increasingly using online learning or e-learning as it is more commonly called, as part of the curriculum. E-learning is the currently fashionable term used to describe the diverse use of information and communications technologies to support and enhance learning, teaching and assessment- from resource-based learning (in which students carry out face to face tasks supplemented by a range of online resources) to fully online courses [2]. Online learning is often used interchangeably with the term e-learning. Brennan et al. [3] describe online delivery as computer technology which enhances, extends and replaces traditional teaching and training practices.

A small number of studies have been carried out in the UAE to investigate the use of e-learning in tertiary education. The majority of studies have focused on the perceptions of the educators about how to integrate the new technologies

Copyright (C) 2010 Lejla Vrazalic, Robert MacGregor, Donna Behl and Jean Fitzgerald. This is an open access article distributed under the Creative Commons Attribution License unported 3.0, which permits unrestricted use, distribution, and reproduction in any medium, provided that original work is properly cited. The article is a reprint from a 2009 article. Contact author: Lejla Vrazalic. E-mail: L.Vrazalic@mdx.ac 
into their teaching and learning, along with their perceptions of the value or not of e-learning in the UAE context. Other local studies focus on language competence and language use to access the Web [4], and the impact of globalism on Arab and Higher Education [5]. A recent study being carried out at Zayed University in the UAE by Birks, Hunt \& Martin [6] researches the use of information literacy web resources by Arabic students. Findings are yet to be released.

This study aims to focus on the actual lived reality of students as they participate in the world of e-learning. Our goal is to ensure that we understand the barriers for students which impact on the effectiveness of their e-learning experiences. It is anticipated that findings will enable the researchers to make suggestions for improving the e-learning and teaching environment for students in the UAE.

\section{Literature Review}

Themes in the literature discussing barriers for students in their e-learning experiences in general throughout the world include the four key areas: Information and communication technology (ICT) environment issues, student characteristics, support for students, and provision of authentic activities. The human resources sector is interested in e-learning as a means of providing accessible training courses for employees. Mungania [7] reported seven types of barriers to e-learning as perceived by 875 employees who had taken e-learning courses. Findings showed the seven types of barriers to be: personal or dispositional; learning style; instructional; situational; organizational; content suitability and technological barriers. In a local Gulf institution, Schoepp [8] undertook a research project which investigated what faculty members at a UAE University perceived to be acting as barriers in their attempts to integrate ICT into their teaching. The most cited barriers to technology integration were: poor administrative support; problems with time, access, space, supervision, and operations; poor software; curriculum integration difficulties; teacher's attitudes and knowledge towards computers; computer limitations and inadequate numbers of computers; and lack of technical support.

Students' access to the internet is one of the main (ICT) environment issues. This is affected by the country's technology structure and connectivity, along with financial reasons related to owning a computer and possible family restrictions on allowing students the freedom to access the internet. The Digital Divide -Barriers to e-learning (University of Adelaide 2006) research project was designed to better understand the barriers for particular groups in the population and explored the barriers of connectivity, capability and content. Access is seen by some as a basic human right.

Placed in context, being able to access ICT's is a privilege enjoyed by a minority of the global population, but for those living in societies where opportunity depends on being able to bridge the digital divide, the deprivation compares to lack of food, shelter and basic survival sources. (Kofi Anan 1999 [9]). Simmons [10] acknowledges that technology is only one of several barriers encountered, contrary to popular claims that barriers are mostly technological.

The second theme of student characteristics include demographic differences in age, gender, learning styles, previous educational experience with technology, and motivation for learning in an e-learning environment. Characteristics of the students involved in this study can be described in general terms, accepting some minor differences will be found. Students in tertiary institutions in the UAE have normally undertaken all their previous education in Arabic, speak English as a second language and have varying levels of English proficiency. Generally students have attended government funded schools that reflect a traditional teaching and learning approach of teacher-centric, rotelearning and memorizations and very limited formats for learning resources [11]. In these two small Gulf countries it is important to note that only a fraction of the mothers and fathers of today's students graduated from high school. As late as 1970 , literacy rates in the UAE hovered just above $20 \%$ [1]. Major education reform over the last five years has called for more integration of ICT in secondary schools but this is occurring only in pockets and more often only in private schools. These deficiencies in provision of rich educational experiences prior to entering the tertiary environment have a significant impact on the design of appropriate teaching and learning strategies. Birks, Hunt \& Martin [6] note that students' learning is generally more teacher-controlled and task directed than would be in a western university. They suggest that tasks and assignments need to be more prescriptive, and independent work be very explicit and task oriented to cope with the cultural differences in current learners from the UAE. 
Self efficacy of learners is also cited as an important measure of student's ability to cope with the new environment of online learning. Social cognitive learning theory informs teachers about the nature of their learners. Self efficacy is described by Mungania \& Reio [12] as a reflection of what individuals believe they can do with the skills they possess. Self efficacy beliefs may contribute to the success with which a task is completed.

Mungania and Reio (ibid) also note that elearners must understand their personal roles and responsibilities in e-learning. Although many changes can be made to the environment in terms of organization, design or technology, each individual must recognize that as an adult learner, one has to take responsibility for one's learning [13]. Results of this survey may verify the perceptions of teaching staff that students are frequently reluctant and unable to adjust to a different system of education where they are expected to take more responsibility for their own learning.

Possible linguistic capability issues may be identified as another barrier to students adapting to the online learning environment. Hughes [14] explored linguistic and cultural factors related to international students' use of online learning resources. She observed: "linguistic factors tended to have more impact on the participants' actual use of online resources while cultural factors had greater influence on their wider educational experience"(p5).

In addition, the choice of acceptable educational practices is intricately tied to culture and tradition, and introduction of a virtual learning environment requires examination of the sociocultural factors which may present cultural barriers. Akinyemi [15] examined the perspectives of Arab students in Oman using Web-based learning, suggested that such students may need a uniquely "Arabised" elearning system and identified a need for further research in this area.

The third theme of support for students includes students' ability to engage with the learning activities independently, teacher competence and understanding of the pedagogy. A recent study undertaken with 48 students from Zayed University in the UAE describes support for students as key to their positive experiences in an e-learning environment [16]. Barriers to engagement with their learning were anxiety, technical problems, inaccessibility, and time pressure. Results from this study revealed that online human interaction can enhance motivation and engagement in the learning process. The Digital Divide-Barriers to elearning study conducted in Australia also highlighted the importance of teachers being competent in the new e-learning environment. Teachers must understand the learning process and the impact of ICT on these processes and the need for specific pedagogy that blends both (University of Adelaide 2006).

The fourth theme identified in literature acknowledges the importance of providing authentic learning tasks for effective teaching and learning. The process of learning is complex. Introducing online delivery as an added part of the process brings added barriers for some students. Brennan's [3] review of the relatively new field of literature about online pedagogy identified dominant themes that reflect concerns with the mechanics of design, questions of access, technological issues and the need for skills development of both teachers and learners. Engaging students in their learning is a challenge in traditional learning environments. Providing exciting tasks and activities is even more important in e-learning activities, without the face to face enthusiasm of the instructor. There are many tools available for teachers to provide authentic learning experiences online for students and to integrate these tools into the curriculum in a meaningful way. Assignments involving real world projects that are both relevant and interesting allow students to be engaged in exploration and enquiry [17].

Further research, which is specific to the UAE context, is required to determine whether these four barrier themes apply and also to examine the reasons why e-learning may not be readily adopted by students and faculty in the UAE, despite the well documented benefits of this type of learning. The study presented here aims to provide preliminary empirical evidence towards achieving this goal.

\section{Methodology}

An survey instrument was developed and administered in online mode using the SelectSurvey system. The participating institutions were selected on a voluntary basis and the data collection was carried out in phases throughout 2007 and 2008. The survey was developed collaboratively by all of the participating institutions and consists of different sections which aim to collect data about student demographics, computer and 
Internet usage, previous experiences with elearning systems and, finally, e-learning barriers. The survey questions were derived based on the literature review and also integrate components of the Technology Acceptance Model [18]. The survey was piloted with 33 students in one of the participating institutions in November 2006 and based on the results of the pilot study, several changes were made to the survey questions to remove ambiguities.

Thirteen e-learning barriers were identified from the literature (see Table 1 below). Respondents were asked to evaluate each of the barriers in Table 1 across a 6 point Likert scale (strongly agree, agree, mildly agree, mildly disagree, disagree, strongly disagree). In addition to other questions, respondents were asked their age (under 18, 18-25, 26-35, over 35) and gender. Respondents were also asked to rate the ease of use, the usefulness and the perceived satisfaction level with e-learning (based on Davis' [18] TAM research) using a 6 point Likert scale (very easy/useful/satisfied, easy/useful/satisfied, mildly easy/ useful/ satisfied, mildly difficult/ useless/ dissatisfied, difficult/ useless/ dissatisfied, very difficult/ useless/ dissatisfied).

Table 1: E-Learning Barriers

\begin{tabular}{|c|c|}
\hline 1 & $\begin{array}{l}\text { I prefer to talk to my teachers instead of } \\
\text { using Moodle, WebCT or Blackboard. }\end{array}$ \\
\hline 2 & $\begin{array}{l}\text { I would prefer to use Moodle, WebCT or } \\
\text { Blackboard in my own language. }\end{array}$ \\
\hline 3 & $\begin{array}{l}\text { Using Moodle, WebCT or Blackboard makes } \\
\text { me feel stressed and anxious. }\end{array}$ \\
\hline 4 & $\begin{array}{l}\text { Moodle, WebCT or Blackboard is complex } \\
\text { and difficult to use. }\end{array}$ \\
\hline 5 & $\begin{array}{l}\text { Moodle, WebCT or Blackboard is not exciting } \\
\text { or interesting to use. }\end{array}$ \\
\hline 6 & $\begin{array}{l}\text { The courses and materials available online } \\
\text { are boring. }\end{array}$ \\
\hline 7 & $\begin{array}{l}\text { I have concerns about the quality of the } \\
\text { educational materials in Moodle, WebCT or } \\
\text { Blackboard. }\end{array}$ \\
\hline 8 & $\begin{array}{l}\text { I don't think using Moodle, WebCT or } \\
\text { Blackboard helps me to learn. }\end{array}$ \\
\hline 9 & $\begin{array}{l}\text { Using Moodle, WebCT or Blackboard is not } \\
\text { the way I prefer to learn because it does not } \\
\text { suit my learning style. }\end{array}$ \\
\hline 10 & $\begin{array}{l}\text { Using Moodle, WebCT or Blackboard is not } \\
\text { compatible with the way we are taught in my } \\
\text { school/college. }\end{array}$ \\
\hline 11 & $\begin{array}{l}\text { I don't have enough time to use Moodle, } \\
\text { WebCT or Blackboard. }\end{array}$ \\
\hline 12 & $\begin{array}{l}\text { I don't feel motivated to use an Moodle, } \\
\text { WebCT or Blackboard. }\end{array}$ \\
\hline 13 & $\begin{array}{l}\text { It is not cool to use Moodle, WebCT or } \\
\text { Blackboard in my school/college. }\end{array}$ \\
\hline
\end{tabular}

A series of linear regressions was applied to the data to determine whether age, gender, ease of use, perceived usefulness or perceived level of satisfaction was associated with the perception of any of the 13 barriers.

\section{Results}

455 students from four public and private tertiary institutions in the UAE took part in the study. The background of the students in each of the institutions varies considerably in terms of both demographics and high school background. As indicated, a series of linear regressions was applied to the data. The results of the linear regressions are shown in Table 2. 
Table 2: Results of the Linear Regressions

\begin{tabular}{|c|c|c|c|c|c|c|c|}
\hline Barrier & $\mathbf{R}^{2}$ & $\begin{array}{c}\text { Adjusted } \\
\mathbf{R}^{2}\end{array}$ & $\begin{array}{l}\text { p value of } \\
\text { Table }\end{array}$ & Factor & Beta & t value & Significance \\
\hline 1 Prefer to talk to teachers & .033 & .023 & .011 & Useful & -.182 & -3.333 & .001 \\
\hline \multirow{2}{*}{$\begin{array}{l}2 \text { Prefer e-learning in own } \\
\text { language }\end{array}$} & .038 & .028 & .005 & Easy & -.114 & -2.069 & .039 \\
\hline & & & & Useful & .161 & 2.950 & .003 \\
\hline \multirow[t]{2}{*}{3 E-learning is stressful } & .067 & .053 & .000 & Easy & -.171 & -3.167 & .002 \\
\hline & & & & Useful & -.127 & -2.371 & .018 \\
\hline \multirow{2}{*}{$\begin{array}{l}4 \text { E-learning is complex and } \\
\text { difficult }\end{array}$} & .136 & .127 & .000 & Easy & -.305 & -5.872 & .000 \\
\hline & & & & Useful & -.111 & -2.145 & .003 \\
\hline \multirow[t]{2}{*}{5 E-learning is not interesting } & .101 & .091 & .000 & Gender & .124 & 2.502 & .013 \\
\hline & & & & Useful & -.278 & -5.265 & .000 \\
\hline 6 Online materials are boring & .085 & .075 & .000 & Useful & -.279 & -5.230 & .000 \\
\hline \multirow{2}{*}{$\begin{array}{l}7 \text { Quality concerns about e- } \\
\text { learning }\end{array}$} & .031 & .021 & .017 & Easy & -.152 & -2.751 & .006 \\
\hline & & & & & & & \\
\hline \multirow{2}{*}{$\begin{array}{l}8 \text { E-learning doesn't help me } \\
\text { learn }\end{array}$} & .225 & .216 & .000 & Useful & -.449 & -9.097 & .000 \\
\hline & & & & & & & \\
\hline \multirow{2}{*}{$\begin{array}{l}9 \text { E-learning does not suit my } \\
\text { learning style }\end{array}$} & .161 & .152 & .000 & Age & .125 & 2.621 & .009 \\
\hline & & & & Useful & -.358 & -6.962 & .000 \\
\hline \multirow{2}{*}{$\begin{array}{l}10 \text { E-learning not compatible } \\
\text { with school style }\end{array}$} & .054 & .044 & .000 & Easy & -.164 & -2.987 & .003 \\
\hline & & & & & & & \\
\hline \multirow{3}{*}{$\begin{array}{l}11 \text { Don't have enough time for } \\
\text { e-learning }\end{array}$} & .086 & .076 & .000 & Gender & -.144 & -2.880 & .004 \\
\hline & & & & Easy & -.148 & -2.757 & .006 \\
\hline & & & & Useful & -.165 & -3.083 & .002 \\
\hline \multirow{2}{*}{$\begin{array}{l}12 \text { Don't feel motivated to use } \\
\text { e-learning }\end{array}$} & .126 & .117 & .000 & Useful & -3.16 & -6.032 & .000 \\
\hline & & & & & & & \\
\hline \multirow[t]{2}{*}{13 E-learning is not cool } & .050 & .040 & .001 & Easy & -.113 & -2.060 & .040 \\
\hline & & & & Useful & -.148 & -2.705 & .007 \\
\hline
\end{tabular}

\section{Discussion}

Before examining the e-learning barriers individually, there are two significant findings that should be noted. Firstly, all 13 e-learning barriers were statistically significantly associated with at least one of the factors (age, gender, ease of use, perceived usefulness or perceived level of satisfaction). The second significant finding was the fact that none of the potential disadvantages was associated with perceived satisfaction with the software platform, Moodle/WebCT/Blackboard. This is contrary to earlier findings that suggest that the use of software is dependant on perceived ease of use, perceived usefulness and perceived satisfaction.

We will now consider each of the findings related to each of the barriers separately.

The barrier "I prefer to talk to my teachers instead of using Moodle, WebCT or Blackboard" is significantly associated with perceived usefulness $(\mathrm{p}=.001)$. The negative Beta value suggests that those who did not find the software platform useful were more likely to prefer to deal with their teachers than those that found the software useful, as might be anticipated.

The barrier "I would prefer to use Moodle, WebCT or Blackboard in my own language" is significantly associated with perceived ease of use and perceived usefulness. The negative Beta value for perceived ease of use indicates that those that found the software difficult are more likely to require it in their own language. The positive Beta value for perceived usefulness indicates that those who thought the software was useful would still prefer it in their own language.

The barrier "Using Moodle, WebCT or Blackboard makes me feel stressed and anxious" is associated with both perceived ease of use 
and perceived usefulness. The negative Beta indicates that those that found the software difficult are more likely to be stressed through its use. The negative Beta for usefulness indicates that those that found the software less useful are more likely to be stressed through its use.

The barrier "Moodle, WebCT or Blackboard is complex and difficult to use" is associated with both perceived ease of use and perceived usefulness. The negative Beta indicates that those that found the software difficult are more likely to say that it is complex to use. The negative Beta for usefulness indicates that those that found the software less useful are more likely to feel that it is complex and difficult to use.

The barrier "Moodle, WebCT or Blackboard is not exciting or interesting to use" is associated with gender and perceived usefulness. The positive Beta for gender indicates that female respondents were more likely to find the software unexciting, compared to males. The negative Beta for usefulness indicates that those that found the software less useful are more likely to find it unexciting.

The barrier "Courses and materials available online are boring" is associated with perceived usefulness. The negative Beta for usefulness indicates that those that found the software less useful are more likely to also feel that materials are boring.

The barrier "I have concerns about the quality of the educational materials in Moodle, WebCT or Blackboard" is associated with perceived ease of use. The negative Beta value for perceived ease of use indicates that those who found the software difficult are more likely to question the quality of associated educational materials.

The barrier "I don't think using Moodle, WebCT or Blackboard helps me to learn" is associated with perceived usefulness. The negative Beta for usefulness indicates that those that found the software less useful are more likely to question whether it helps them learn.

The barrier "Using Moodle, WebCT or Blackboard is not the way I prefer to learn because it does not suit my learning style" is associated with age and perceived usefulness. The positive Beta for age indicates that it is the older respondents that are more concerned with this disadvantage. The negative Beta for usefulness indicates that those that found the software less useful are more likely to feel that it doesn't suit their style of learning.
The barrier "Using Moodle, WebCT or Blackboard is not compatible with the way we are taught in my school/college" is associated with ease of use. The negative Beta value for perceived ease of use indicates that those that found the software difficult are more likely to question its compatibility with the way they are being taught.

The barrier "I don't have enough time to use Moodle, WebCT or Blackboard" is associated with gender, ease of use and perceived usefulness. The negative Beta for gender indicates that it is the male respondents, rather than the female respondents that feel they do not have enough time. The negative Beta value for perceived ease of use indicates that those that found the software difficult are more likely to feel that they have not got enough time to use Moodle, WebCT or Blackboard. The negative Beta for usefulness indicates that those that found the software less useful are more likely to feel that they don't have enough time.

The barrier "I don't feel motivated to use an Moodle, WebCT or Blackboard" is associated with perceived usefulness. The negative Beta for usefulness indicates that those that found the software less useful are more likely indicated their lack of motivation.

The final barrier "It is not cool to use Moodle, WebCT or Blackboard in my school/college" is associated with perceived ease of use and perceived usefulness. The negative Beta value for perceived ease of use indicates that those that found the software difficult are more likely to feel that it is not cool to use the software. The negative Beta for usefulness indicates that those that found the software less useful are, likewise, more likely to indicate that it is not cool to use the software.

\section{Conclusion and Implications}

The preliminary findings of our study indicate the need for further research and investigation into how e-learning barriers are perceived by students in the UAE. While the gender of the students was associated with a lack of interest for e-learning, as well as a lack of time to use elearning, the relationship needs to be studied further. The data suggests that female students found e-learning to be less exciting, but male students had less time to use this type of learning. Of particular interest is the association between the usefulness of e-learning and elearning barriers, which requires additional analysis. The lack of associations between elearning barriers and student satisfaction is also worth noting. 
Once fully available, the findings of this study will inform teachers and administration in tertiary education institutions in the UAE about key areas to address in relation to the use of online delivery in their programmes. The four main areas of student characteristics, ICT environment issues, support for students and authentic activities are expected to be highlighted through the findings of the surveys. It is also expected that the educational and technological backgrounds of students will make a significant difference to their e-learning experiences.

It is evident from the literature in the area that unless the pedagogy of online delivery is addressed, it can itself be a barrier to student learning. The ever increasing investment into growth of e-learning technologies for instructional delivery makes it imperative to determine and address the barriers to elearning for students and the results of the study presented here will help achieve this goal.

\section{Limitations}

It should be noted that the study presented here has several limitations. The choice of variables selected for the study is somewhat problematic because of the complex nature of e-learning barriers. Furthermore, only those interested in the study completed the survey. Finally, this is a quantitative study, and further qualitative research is required to gain a better understanding of the key issues.

\section{References}

[1] Walters, T.,\& Quinn, S. (2003). Living Books: A culturally sensitive, adaptive e-Education process, paper presented at the SSGRR International conference on Advances in infrastructure for e-business, e-education, $e$ science, s-medicine and Mobile Technologies on the Internet, L'Aquila, Italy.

[2] Fitzgerald, J. (2006). IT blended and elearning learning committee. Presented at $\mathrm{Abu}$ Dhabi Women's College in-house PD forum. Accessed May 2006 from http://www.elearningcentre.co.uk/.

[3] Brennan, R. (2003). One size doesn't fit all, in Guthrie, H. (ed) (2003) Online learning: research findings, NCVER and ANTA (55-68).

[4] Peel, R. (2004). The Internet and language use: A Case Study in the United Arab Emirates, International Journal on Multicultural Studies. 6 (1), 79-91.
[5] Findlow, S. (2006). Higher education and linguistic dualism in the Arab Gulf, British Journal of Sociology in Education, 27(1), 19-36.

[6] Birks, J., Hunt, F. \& Martin, J. (2007). Research into the use of information literacy web resources by Arabic Students. Zayed University, UAE.

[7] Mungania, P. (2003). The seven e-learning barriers facing employees. Report for Masie Centre learning consortium. Accessed May 2007 http://www.masie.com/ researchgrants/2003/Mungania_Final_Report.p df.

[8] Schoepp, K. (2005). Barriers to integration in a technology rich environment. Learning and Teaching in Higher Education: Gulf perspective, (2), 1-24.

[9] ANTA (Australia National Training Authority), 2002: 8.

[10] Simmons, D.E. (2002). The forum report: Elearning adoption rates and barriers, In A. Rossett (Ed.). The ASTD e-learning handbook: Best practices, strategies and case studies for an emerging field, (pp. 19-23). New York: McGraw Hill.

[11] Mynard, J. (2003). Synchronous computermediated communication and learner autonomy in female Emirati learners of English. University of Exeter.

[12] Mungania, P \& Reio, T.G. Jr. If E-Learners get there, will they stay? The role of e-learning selfefficacy. Online Submission (2005). ERIC. 8 May 2007. http://search.ebscohost.com.

[13] Knowles, M.S.(1990). The adult learner: $A$ neglected species. $4^{\text {th }}$ ed. Houston:TX: Gulf Publishing Co.

[14] Hughes, H. (2005). Actions and reactions: Exploring International Students' use of online information resources. Australian academic and research libraries, 36(4), 169-179.

[15] Akinyemi, A. (2005). Web-Based Learning and Cultural Interference: Perspectives of Arab Students. In Orey, M., McLendon, J. \& Branch, R.M. (Eds.), Educational Media and Technology Yearbook 2005 (pp. 145-9). Wesport, CT: Libraries Unlimited.

[16] Patronis, M. (2005). Motivational constructs in an online learning environment in a UAE university. Accessed May 5, 2007. www.admc.hct.ac.ae/emel2005/people/patroni s/MP\%20Paper2005.doc. 
[17] MacEntee, V.M. and Wells, S.J. The use of technology to facilitate authentic Learning. Proceedings from 2005 Informing Science and IT Education conference. Flagstaff, Arizona, June 16-19, 2005.

[18] Davis, F. D. (1989). Perceived usefulness, perceived ease of use, and user acceptance of information technology. MIS Quarterly, 13(3), 319-340.

\section{Acknowledgements}

We acknowledge the collaborative team of colleagues from the following UAE and Omani tertiary institutions who contributed to this research project and specifically the development of the survey instrument: HCT Dubai Women's College, HCT Abu Dhabi Women's College, University of Wollongong in Dubai, Zayed University, American University of Sharjah and Sultan Qaboos University. 